\title{
Thermodynamic and Experimental Studies on Al Addition of 253MA Steel
}

\author{
Yandong $\mathrm{Li}^{1}{ }^{1}$, Tongsheng Zhang ${ }^{2, *}$, Chengjun Liu $^{3}$ and Maofa Jiang ${ }^{3}$ \\ 1 Key Laboratory of Extraordinary Bond Engineering and Advanced Materials Technology, \\ Yangtze Normal University, Chongqing 408000, China; andyydlee@gmail.com \\ 2 School of Metallurgy and Environment, Central South University, Changsha 410083, China \\ 3 Key Laboratory of Ecological Utilization of Multi-Metallic Mineral of Education Ministry, \\ Northeastern University, Shenyang 110819, China; neu_zts@163.com (C.L.); anxin1984@126.com (M.J.) \\ * Correspondence: tongsheng.zhang@csu.edu.cn; Tel.: +86-139-7498-2473
}

Received: 27 March 2019; Accepted: 10 April 2019; Published: 12 April 2019

\begin{abstract}
To solve the nozzle clogging issue in the continuous casting process of 253MA steel, a method of modifying solid inclusions to liquid phases is proposed. The CALPHAD technique was employed to predict the liquid region of the $\mathrm{Al}_{2} \mathrm{O}_{3}-\mathrm{SiO}_{2}-\mathrm{Ce}_{2} \mathrm{O}_{3}$ system. Then a thermodynamic package based on the extracted data during the phase diagram optimization process was developed. This package was then used to compute the appropriate aluminum addition, which was $0.01 \%$ in 253MA steel. The Si-Al alloy was chosen as the deoxidant according to the thermodynamic analysis. The solid inclusions were ultimately modified to liquid phases at $1500{ }^{\circ} \mathrm{C}$ when cerium was added through the equilibrium experiments in a $\mathrm{MoSi}_{2}$ tube furnace.
\end{abstract}

Keywords: CALPHAD; thermodynamic model; inclusions; rare earth

\section{Introduction}

Rare earth elements (REs) are widely used in metallurgical, chemical, and advanced materials products [1-3]. REs were used to improve the quality of steel or slag. For example, the refining slag of $\mathrm{CaO}-\mathrm{AlO}_{3}-\mathrm{MgO}-\mathrm{SiO}_{2}$ systems containing $\mathrm{Ce}_{2} \mathrm{O}_{3}$ promotes the absorption of $\mathrm{Al}_{2} \mathrm{O}_{3}$ inclusions [4]. The 253MA steel is developed by adding $0.03-0.08 \%$ of cerium into the $21 \mathrm{Cr}-11 \mathrm{Ni}$ austenitic steel. The high temperature oxidation resistance of 253MA steel is superior to $310 \mathrm{~S}$ stainless steel (25Cr-20Ni) with higher nickel addition [5,6]. However, the phase diagrams or thermodynamic data involving multicomponent- $\mathrm{RE}_{2} \mathrm{O}_{3}$ are missing, which restricts the further study and application of rare earth elements in metallurgy [7-9]. What's more, a large amount of fine and dispersed inclusions, such as $\mathrm{RE}_{2} \mathrm{O}_{3}$ and $\mathrm{RE}_{2} \mathrm{O}_{2} \mathrm{~S}$, are formed after the molten steel are alloyed by REs since the strong attaching power between $\mathrm{O}, \mathrm{S}$, and REs. These inclusions are easily attached to the inner wall and cause principle inducement of the nozzle clogging during the continuous casting, which deteriorate the productivity and the quality of production $[10,11]$.

The clogging problems can usually be relieved by modifying the material or shape of submerged nozzle and calcium treatment [11-13]. Calcium treatment is the primary choice for dealing with the clogging issue of Al-killed steel by modifying $\mathrm{Al}_{2} \mathrm{O}_{3}$ to liquid phases at the casting temperature $[14,15]$. Kojola et al. demonstrated that the clogging frequency is remarkably reduced when 253MA steel is alloyed in the proper order of aluminum, cerium, and silicon [10]. The mechanism of Ca treatment for Al-killed steel might be similar to the Al treatment of Si-killed Ce-bearing steel, which is the generation of liquid inclusions, although the author gave the hypothesis that small inclusions might decompose after Si addition without sampling and analyzing the inclusions. To explain the declined clogging rate phenomenon in Kojola's experiments, the CALPHAD (CALculation of PHAse Diagrams) technique 
was introduced to obtain thermodynamic data of complex oxide systems containing REs. Then the thermodynamic model and package, as well as physical simulation at steelmaking temperature were employed to study the inclusions evolution behaviors in 253MA steel.

\section{Research Methods}

The technology routine is shown in Figure 1. The liquid or glass formation regions have been reported in $\mathrm{Al}_{2} \mathrm{O}_{3}-\mathrm{SiO}_{2}-\mathrm{Y}_{2} \mathrm{O}_{3} / \mathrm{La}_{2} \mathrm{O}_{3} / \mathrm{Sm}_{2} \mathrm{O}_{3}$ systems. However, the liquid boundary of $\mathrm{Al}_{2} \mathrm{O}_{3}-\mathrm{SiO}_{2}$ system involving $\mathrm{Ce}_{2} \mathrm{O}_{3}$ is unclear. For this reason, the Redlish-Kister polynomial expression and Kohler's extrapolation model in FactSage software were employed to optimize the phase diagram of $\mathrm{Al}_{2} \mathrm{O}_{3}-\mathrm{SiO}_{2}-\mathrm{Ce}_{2} \mathrm{O}_{3}$ systems [16,17]. Then the interaction parameters and excess Gibbs free energy $\left(G^{\mathrm{E}}\right)$ were extracted during the optimization. Then the $G^{\mathrm{E}}$ were used to calculate the standard Gibbs free energy of liquid inclusions $\left(x \mathrm{Ce}_{2} \mathrm{O}_{3} \cdot y \mathrm{Al}_{2} \mathrm{O}_{3} \cdot(1-x-y) \mathrm{SiO}_{2}\right.$, where $\left.0<x<1,0<y<1-x\right)$ to represent the chemical equilibrium of every reactions based on Wagner's relations in the infinite dilute solution of molten steel, which is always adopted in steelmaking and is different from the minimum total Gibbs energy principle in FactSage software [18].

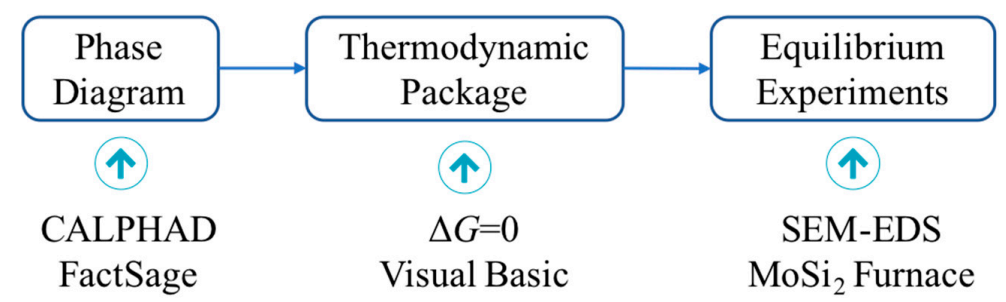

Figure 1. Research routine in this work.

The thermodynamic calculations were conducted by the Main.exe file compiled with the Visual Basic software (version 6.0, Microsoft Company, Redmond, WA, USA). The results were outputted in the format of .txt (as shown in the result module of Figure 2) and . $x l_{s} x$. As shown in Figure 2, the initial input variants were temperature, calculation step, and original compositions of alloy elements.

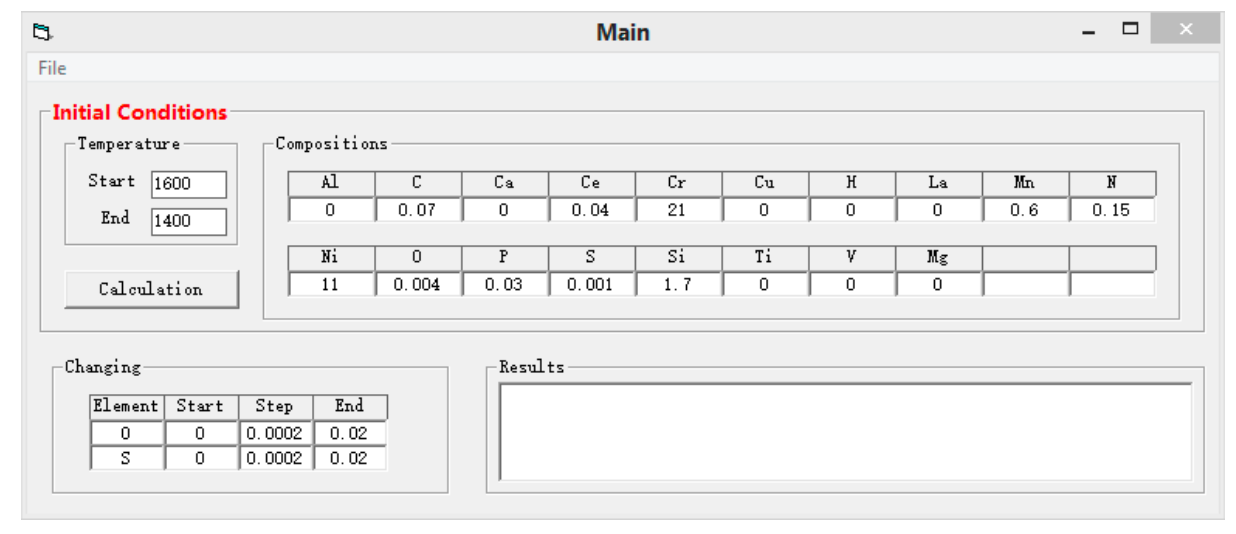

Figure 2. Main interface of the developed program.

According to the thermodynamic calculations, the Si-Al alloy was chosen and the 253MA steel was melt in the tube furnace heated with $8 \mathrm{MoSi}_{2}$ units (shown as Figure 3) at $1600{ }^{\circ} \mathrm{C}$ when the raw materials were collected in a $\mathrm{MgO}$ crucible placed in a graphite crucible in argon atmosphere. The materials used to melt the 253MA steel are listed in Table 1. Molten steel samples were extracted by a quartz tube at 1600 and $1500{ }^{\circ} \mathrm{C}$ and then quenched into the ice-water mixture to reserve the original morphologies of inclusions at the steelmaking and casting temperature, respectively. The quenched samples were polished and observed by the FE-SEM (field emission scanning electron microscope, JEOL, Tokyo, Japan) and EDS (energy dispersive spectrometer, JEOL, Tokyo, Japan). 


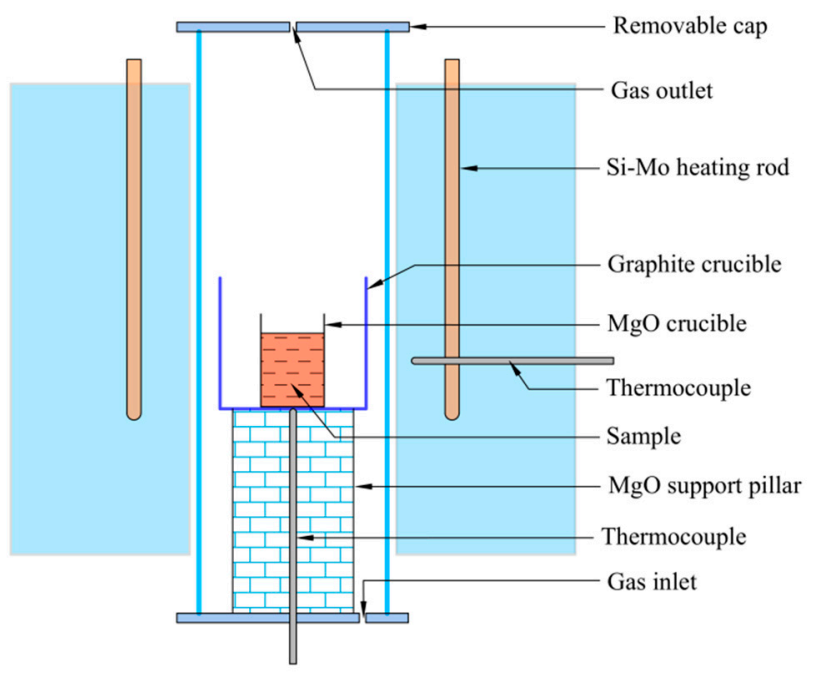

Figure 3. Schematic diagram of the tube furnace.

Table 1. Chemical compositions of melting alloys.

\begin{tabular}{cccccccccccc}
\hline Raw Material & $\mathbf{C}$ & $\mathbf{S i}$ & $\mathbf{M n}$ & $\mathbf{P}$ & $\mathbf{S}$ & $\mathbf{N}$ & $\mathbf{A l}$ & $\mathbf{C r}$ & $\mathbf{N i}$ & $\mathbf{C e}$ & $\mathbf{F e}$ \\
\hline $\mathrm{Fe}$ & 0.002 & 0.01 & 0.02 & 0.005 & 0.003 & - & 0.018 & 0.02 & 0.01 & - & 99.9 \\
$\mathrm{Ni}$ & 0.01 & 0.002 & - & 0.001 & 0.001 & - & - & - & 99.96 & - & 0.01 \\
$\mathrm{Cr}$ & 0.008 & 0.21 & - & 0.003 & 0.0015 & 0.05 & 0.21 & 99.1 & - & - & 0.16 \\
$\mathrm{Si}-\mathrm{Al}$ & 0.068 & 75.7 & 0.24 & 0.026 & 0.005 & - & 1.3 & - & - & - & 22.61 \\
$\mathrm{Ce}$ & 0.08 & 0.045 & - & - & - & - & - & - & - & 99.4 & - \\
\hline
\end{tabular}

\section{Results and Discussion}

Optimized liquid regions in the phase diagram of $\mathrm{Al}_{2} \mathrm{O}_{3}-\mathrm{SiO}_{2}-\mathrm{Ce}_{2} \mathrm{O}_{3}$ (A-S-C) system by CALPHAD technology is given in Figure 4. The boundaries of full liquid (liquidus) in the A-S-C system have been compared to those in A-S-RE systems [19-21]. It can be seen that the liquid regions in the phase diagram of A-S-RE systems were almost located in similar sections, near the $\mathrm{SiO}_{2}$ corner and symmetrically distributed on the isometric line of mole fraction ratio of $\mathrm{RE}_{2} \mathrm{O}_{3}$ and $\mathrm{Al}_{2} \mathrm{O}_{3}$ was 1 . This is due to the similar physical and chemical properties of rare earth elements, especially the lanthanide series. The existence of the liquid regions implies it is possible to modify the fine solid inclusions to liquid phases.

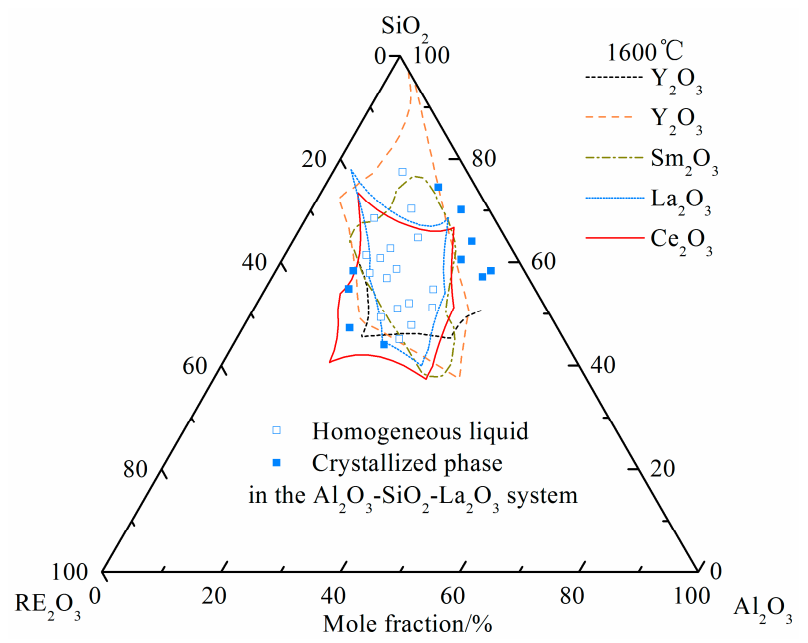

Figure 4. Liquid regions of $\mathrm{Al}_{2} \mathrm{O}_{3}-\mathrm{SiO}_{2}-\mathrm{RE}_{2} \mathrm{O}_{3}$ systems. 
During optimization of the of A-S-C phase diagram system, the excess Gibbs free energy of the complex liquid inclusions $\left(x \mathrm{Ce}_{2} \mathrm{O}_{3} \cdot y \mathrm{Al}_{2} \mathrm{O}_{3} \cdot(1-x-y) \mathrm{SiO}_{2}\right)$ deviating from ideal mixture of $\mathrm{Ce}_{2} \mathrm{O}_{3}, \mathrm{Al}_{2} \mathrm{O}_{3}$ and $\mathrm{SiO}_{2}$ was extracted as follow:

$$
\begin{aligned}
& x \mathrm{Ce}_{2} \mathrm{O}_{3}(1)+y \mathrm{Al}_{2} \mathrm{O}_{3}(1)+(1-x-y) \mathrm{SiO}_{2}(1)=x \mathrm{Ce}_{2} \mathrm{O}_{3} \cdot y \mathrm{Al}_{2} \mathrm{O}_{3} \cdot(1-x-y) \mathrm{SiO}_{2}(1) \\
& G^{\mathrm{E}}=-825000 x y(1-x-y)^{2}+42569.73 x y+19570.28 y(1-y)-140979.96 x(1-x)+ \\
& \frac{y(1-x-y)(1-x-2 y)}{1-x}\left(14875.48+5640.02 \frac{1-x-2 y}{1-x}\right)+\frac{x(1-x-y)(1-2 x-y)}{1-y}[215301.91+ \\
& \left.547791.07 \frac{1-2 x-y}{1-y}+398115.65\left(\frac{1-2 x-y}{1-y}\right)^{2}\right]+\{-98.65 x y-10.49 y(1-y)+78.91 x(1-x)+ \\
& \frac{y(1-x-y)(1-x-2 y)}{1-x}\left(-0.71+1.21 \frac{1-x-2 y}{1-x}\right)+\frac{x(1-x-y)(1-2 x-y)}{1-y}\left[23.6-202.71 \frac{1-2 x-y}{1-y}-\right. \\
& \left.\left.155.94\left(\frac{1-2 x-y}{1-y}\right)^{2}\right]\right\} T
\end{aligned}
$$

Equation (1) is used to calculate the Gibbs free energy of liquid inclusions generation. For other reactions of the solid inclusions generation, the equations are not listed in this work since they can be referenced from thermodynamic handbooks.

Based on the obtained thermodynamic data, we built the model and package of equilibrium calculation of multi-reactions including the liquid inclusions generation. The computed results are shown in Figure 5. As presented in Figure 5a, the liquid inclusions were stable in the region surrounded by the red dashed line as the mass fractions of aluminum and cerium were feasible. When the mass fraction of cerium was $0.02 \%$, the inclusions in the 253MA steel transferred from $\mathrm{Ce}_{2} \mathrm{Si}_{2} \mathrm{O}_{7}$ to liquid phases as the increase of aluminum addition, and cerium aluminates were formed as the aluminum content excess $0.017 \%$, shown in Figure $5 b$. When the mass fraction of cerium was $0.03 \%$, the inclusions first transferred from cerium silicates to liquid phase, and the amount of liquid inclusions began to decline as $\mathrm{CeAlO}_{3}$ appeared, shown in Figure $5 \mathrm{c}$. When the mass fraction of cerium increased to $0.04 \%$, the liquid inclusions precipitated first and then disappeared as the aluminum addition reached $0.015 \%$, Figure $5 \mathrm{~d}$. Considering the required cerium content of $0.03-0.04 \%$ in $253 \mathrm{MA}$ steel, the aluminum addition should be the key factor of restricting the inclusions to liquid, which was about $0.01 \%$.

According to the above thermodynamic calculations, only $0.01 \%$ aluminum was needed to transfer the solid inclusions to liquid phases, then the $\mathrm{Si}-\mathrm{Al}$ alloy, the chemical compositions are listed in Table 1, and were chosen as the deoxidant. The SEM observation and EDS analysis results of sampled inclusions from equilibrium experiments at steelmaking and casting temperature are present in Figure 6. It can be seen that, the inclusions were almost $\mathrm{Al}-\mathrm{Si}-\mathrm{O}$ system after $\mathrm{Si}-\mathrm{Al}$ alloy was added for $60 \mathrm{~min}$. The inclusions were mainly $\mathrm{Ce}_{2} \mathrm{O}_{3} / \mathrm{Ce}_{2} \mathrm{O}_{2} \mathrm{~S}$ after cerium was added for $5 \mathrm{~min}$. The morphologies and compositions changed during the following $25 \mathrm{~min}$, and finally the spherical and liquid inclusions were formed at $1500^{\circ} \mathrm{C}$ (the casting temperature). Altogether, the results showed that the solid inclusions were modified to liquid ones after aluminum was first added in the form of Si-Al alloy and then cerium was added. Nevertheless, it should take more than $30 \mathrm{~min}$ to finish the modifying process after cerium addition. The mechanism of the modifying process can be explained as: (1) the inclusions of Al-Si-O system are formed after Si-Al alloy is added; (2) a number of $\mathrm{Ce}_{2} \mathrm{O}_{3} / \mathrm{Ce}_{2} \mathrm{O}_{2} \mathrm{~S}$ are formed immediately after cerium is added owing to the strong chemical reaction between cerium and oxygen solutes, and the oxygen activity in molten steel is sharply declined; (3) the early generated Al-Si-O inclusions decomposed to solutes of aluminum, silicon, and oxygen since the decline of oxygen activity; (4) the reactions between $\mathrm{Ce}_{2} \mathrm{O}_{3} / \mathrm{Ce}_{2} \mathrm{O}_{2} \mathrm{~S}$ and silicon, aluminum, oxygen keep going on as the continuous diffusion of solutes in molten steel; and (5) the liquid inclusions are ultimately formed as the schematic diagram shown in Figure 6. 


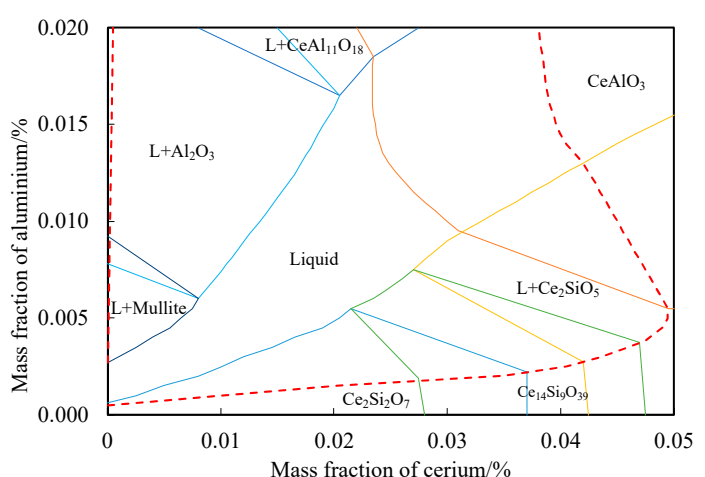

(a)

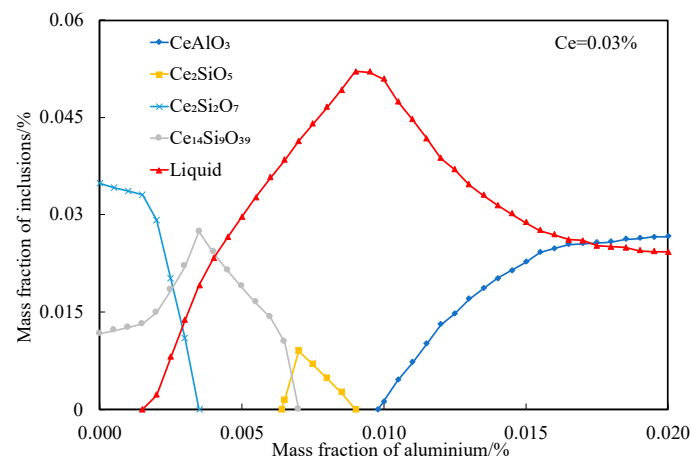

(c)

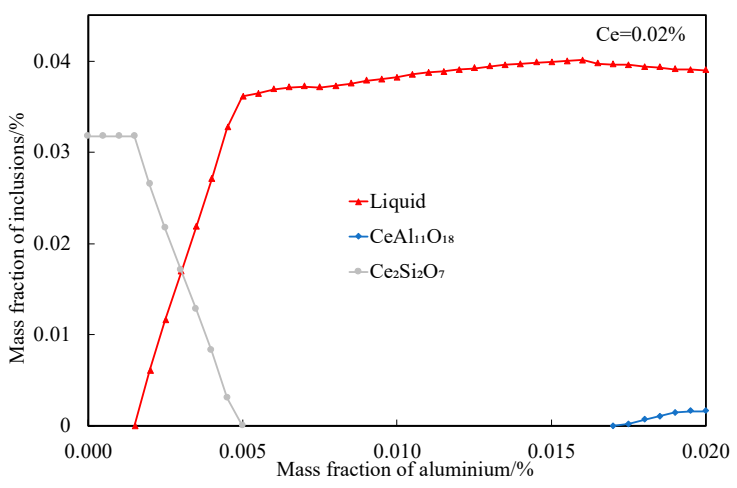

(b)

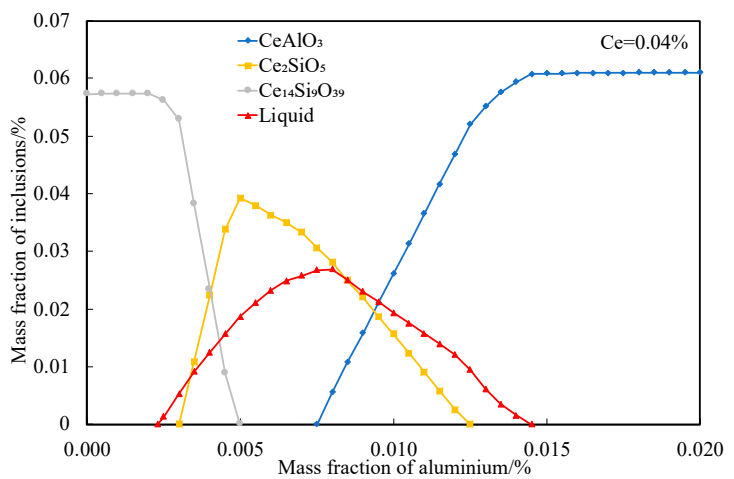

(d)

Figure 5. Calculation results by developed thermodynamic package. (a) Liquid regions of inclusions; (b) Effect of aluminum addition on inclusions, $w_{\mathrm{Ce}}=0.02 \%$; (c) Effect of aluminum addition on inclusions, $w_{\mathrm{Ce}}=0.03 \%$; (d) Effect of aluminum addition on inclusions, $w_{\mathrm{Ce}}=0.04 \%$.

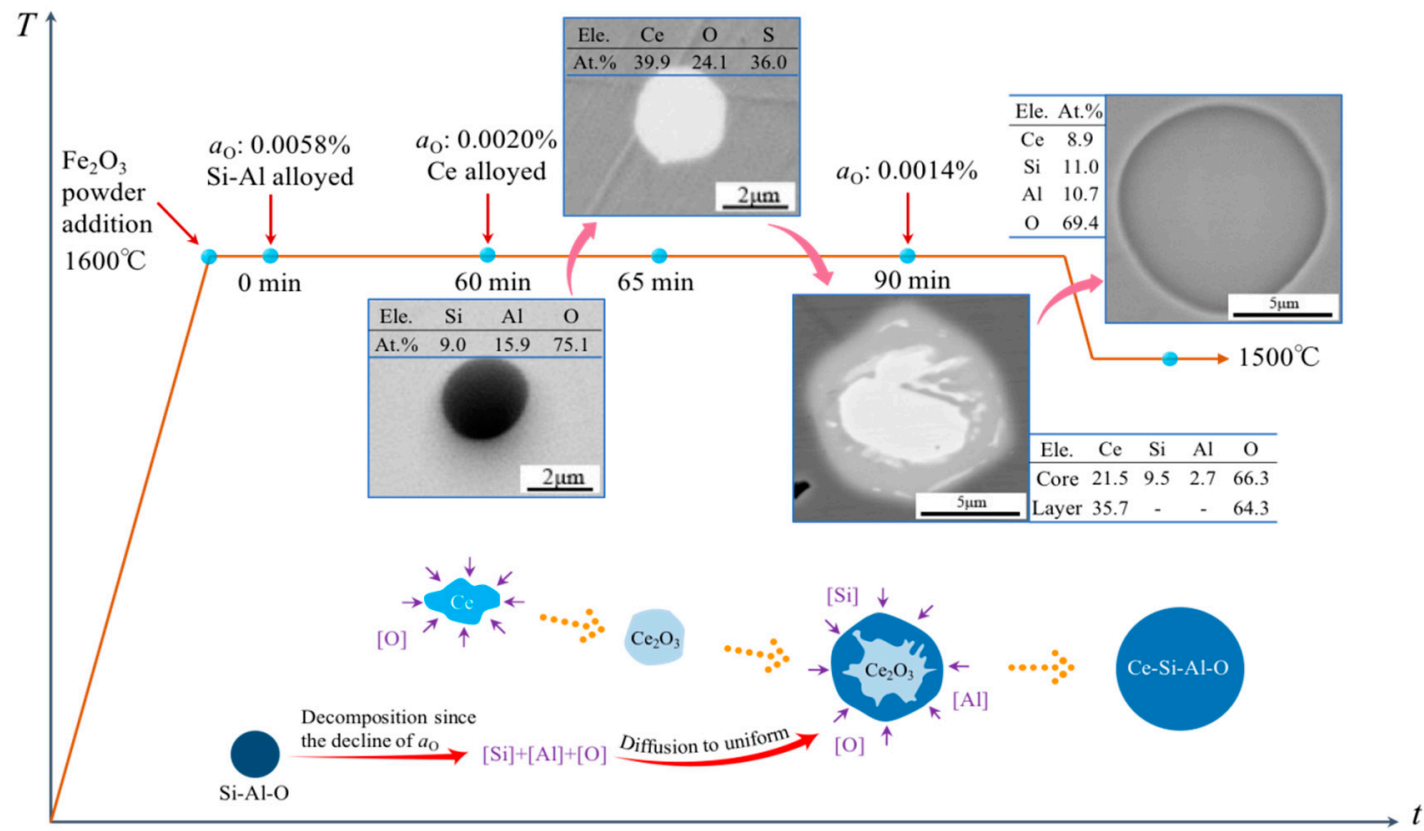

Figure 6. Inclusions evolution in 253MA steel after $\mathrm{Al}$ addition. 


\section{Conclusions}

The liquid region is near the $\mathrm{SiO}_{2}$ corner in the phase diagram of $\mathrm{Al}_{2} \mathrm{O}_{3}-\mathrm{SiO}_{2}-\mathrm{Ce}_{2} \mathrm{O}_{3}$ systems optimized by the CALPHAD technique, implying the possibility of modifying $\mathrm{Ce}_{2} \mathrm{O}_{3} / \mathrm{Ce}_{2} \mathrm{O}_{2} \mathrm{~S}$ to liquid phases. Then the thermodynamic model coded in the user defined package computes the appropriate aluminum addition, about $0.01 \%$, to control the inclusion compositions' inner boundaries of liquid region. The spherical liquid inclusions are found after $30 \mathrm{~min}$ of cerium addition when $\mathrm{Si}-\mathrm{Al}$ alloys are chosen as the deoxidant instead of pure silicon. The thermodynamic and experimental results can support the theory and data groundwork to remit the nozzle clogging of 253MA steel in the future.

Author Contributions: Conceptualization, methodology Y.L. and C.L.; Validation, T.Z.; Writing-review and editing, Y.L.; Supervision, C.L.; Funding acquisition, T.Z. and M.J.

Funding: This research was funded by Natural Science Foundation of Chongqing (cstc2018jcyjAX0792), Open Project from Key Laboratory of Ecological Utilization of Multi-metallic Mineral of Education Ministry (NEMM2018003), Research Project from Chongqing Committee of Education (KJQN201801408, KJZD-M201801401) and the Introduce Talents Research Start-up Fund in Central South University of China.

Conflicts of Interest: The authors declare no conflict of interest.

\section{References}

1. Qi, J.; Liu, C.J.; Zhang, C.; Jiang, M. Effect of $\mathrm{Ce}_{2} \mathrm{O}_{3}$ on structure, viscosity, and crystalline phase of $\mathrm{CaO}-\mathrm{Al}_{2} \mathrm{O}_{3}-\mathrm{Li}_{2} \mathrm{O}-\mathrm{Ce}_{2} \mathrm{O}_{3}$ slags. Metall. Mater. Trans. B 2017, 48, 11-16. [CrossRef]

2. Wang, X.; Ou, D.R.; Shang, L.; Zhao, Z.; Cheng, M. Sealing performance and chemical compatibility of SrO- $\mathrm{La}_{2} \mathrm{O}_{3}-\mathrm{Al}_{2} \mathrm{O}_{3}-\mathrm{SiO}_{2}$ glasses with bare and coated ferritic alloy. Ceram. Int. 2016, 42, 14168-14174. [CrossRef]

3. Iftekhar, S.; Pahari, B.; Okhotnikov, K.; Jaworski, A.; Stevensson, B.; Grins, J.; Edén, M. Properties and structures of $\mathrm{RE}_{2} \mathrm{O}_{3}-\mathrm{Al}_{2} \mathrm{O}_{3}-\mathrm{SiO}_{2}(\mathrm{RE}=\mathrm{Y}, \mathrm{Lu})$ glasses probed by molecular dynamics simulations and solid-state NMR: The roles of aluminum and rare-earth Ions for dictating the microhardness. J. Phys. Chem. C 2012, 116, 18394-18406. [CrossRef]

4. Yang, X.H.; Long, H.; Cheng, G.G.; Wu, C.C.; Wu, B. Effect of refining slag containing $\mathrm{Ce}_{2} \mathrm{O}_{3}$ on steel cleanliness. J. Rare Earths 2011, 29, 1079-1083. [CrossRef]

5. Chen, L.; Ma, X.; Wang, L.; Ye, X. Effect of rare earth element yttrium addition on microstructures and properties of a 21Cr-11Ni austenitic heat-resistant stainless steel. Mater. Des. 2011, 32, 2206-2212. [CrossRef]

6. Matway, R.J.; McGuire, M.F.; Mehta, J. Steel Alloy Having Improved Creep Strength. U.S. Patent 5,393,487, 28 February 1995.

7. Liu, C.J.; Qiu, J.Y.; Sun, L.F. Liquidus and phase equilibrium in $\mathrm{CaO}-\mathrm{SiO}_{2}-\mathrm{Nb}_{2} \mathrm{O}_{5}-10 \% \mathrm{La}_{2} \mathrm{O}_{3}$ system. ISIJ Int. 2018, 58, 612-619. [CrossRef]

8. Qiu, J.Y.; Liu, C.J. Subsolidus phase relations in the $\mathrm{CaO}-\mathrm{SiO}_{2}-\mathrm{Nb}_{2} \mathrm{O}_{5}-\mathrm{La}_{2} \mathrm{O}_{3}$ quarternary system at $1273 \mathrm{~K}$. ISIJ Int. 2017, 57, 2107-2114. [CrossRef]

9. Liu, C.J.; Qiu, J.Y. Phase equilibrium relations in the specific region of $\mathrm{CaO}-\mathrm{SiO}_{2}-\mathrm{La}_{2} \mathrm{O}_{3}$ system. J. Eur. Ceram. Soc. 2018, 39, 2090-2097. [CrossRef]

10. Kojola, N.; Ekerot, S.; Jönsson, P. Pilot plant study of clogging rates in low carbon and stainless steel grades. Ironmak. Steelmak. 2011, 38, 81-89. [CrossRef]

11. Zhou, S.C. Study of the clogging of the submersible nozzle in the continuous casting of stainless steel RE-253MA. Metallurgist 2013, 57, 510-515.

12. Memarpour, A. An Experimental Study of Submerged Entry Nozzles (SEN) Focusing on Decarburization and Clogging; Dalarna University: Falun, Sweden, 2011.

13. Memarpour, A.; Brabie, V.; Jönsson, P.G. Studies of effect of glass/silicon powder coatings on clogging behaviour of submerged entry nozzles when using REM alloyed stainless steels. Ironmak. Steelmak. 2011, 38, 229-239. [CrossRef]

14. Tuttle, R.B.; Smith, J.D.; Peaslee, K.D. Casting simulation of calcium Titanate and calcium Zirconate nozzles for continuous casting of aluminum-killed steels. Metall. Mater. Trans. B 2007, 38, 101-108. [CrossRef]

15. McPherson, N.A.; McLean, A. Continuous Casting Volume 6-Tundish Tomold Transfer Operations; Iron and Steel Society: Warrendale, PA, USA, 1992. 
16. Redlich, O.; Kister, A.T. Algebraic representation of thermodynamic properties and the classification of solutions. Ind. Eng. Chem. 1948, 40, 345-348. [CrossRef]

17. Pelton, A.D. A general "geometric" thermodynamic model for multicomponent solutions. Calphad 2001, 25, 319-328. [CrossRef]

18. Li, Y.D.; Liu, C.J.; Zhang, T.S.; Jiang, M.F.; Peng, C. Liquid inclusions in heat-resistant steel containing rare earth elements. Metall. Mater. Trans. B 2017, 48, 956-965. [CrossRef]

19. Bondar, I.A.; Galakhov, F.Y. Phase equilibria in the system $\mathrm{Y}_{2} \mathrm{O}_{3}-\mathrm{SiO}_{2}-\mathrm{Al}_{2} \mathrm{O}_{3}$. Bull. Acad. Sci. USSR Div. Chem. Sci. 1964, 13, 1231-1232. [CrossRef]

20. Kolitsch, U.; Seifert, H.J.; Ludwig, T.; Aldinger, F. Phase equilibria and crystal chemistry in the $\mathrm{Y}_{2} \mathrm{O}_{3}-\mathrm{Al}_{2} \mathrm{O}_{3}-\mathrm{SiO}_{2}$ system. J. Mater. Res. 1999, 14, 447-455. [CrossRef]

21. Kolitsch, U.; Seifert, H.J.; Aldinger, F. Phase relationships in the system $\mathrm{Gd}_{2} \mathrm{O}_{3}-\mathrm{Al}_{2} \mathrm{O}_{3}-\mathrm{SiO}_{2}$. J. Alloys Compd. 1997, 257, 104-114. [CrossRef]

(C) 2019 by the authors. Licensee MDPI, Basel, Switzerland. This article is an open access article distributed under the terms and conditions of the Creative Commons Attribution (CC BY) license (http://creativecommons.org/licenses/by/4.0/). 